\title{
THE EFFECT OF HOME CARE FOR STROKE PATIENTS AND EDUCATION OF CAREGIVERS ON THE CAREGIVER BURDEN AND QUALITY OF LIFE*
}

\begin{abstract}
Hacer Gok Ugur ${ }^{1}$ and Behice Erci ${ }^{2}$
${ }^{1}$ Department of Public Health Nursing, Ordu University Faculty of Health Sciences, Ordu, Turkey; ${ }^{2}$ Department of Public Health Nursing, Inonu University Nursing Faculty, Malatya, Turkey

SUMMARY - The aim of this study was to determine the effect of home care provided for stroke patients and education of caregivers on the caregiver burden and quality of life. The study was conducted by using a true experimental method with pre-test and post-test control group. The study included 43 experimental and 43 control patients and their caregivers. The Patient and Caregiver Description Form, Patient Problem Identifying Form, Caregiving Burden Scale and SF-36 Quality of Life Scale were used to collect data in the study. Nursing care was provided to the experimental group patients according to the model of daily living activities, while their caregivers received training and consultancy. In the control group, there was no such intervention. Percentage distribution, $\chi^{2}$, independent sample t-test, paired t-test, Mann-Whitney $\mathrm{U}$ test, and Wilcoxon signed-rank tests were used on statistical analyses. There was no significant difference in pre-test score means between experimental and control group caregivers. However, a statistically significant difference was found in all sub-dimensions of the quality of life scale between pre-test and post-test score means in the experimental group caregivers. This study results indicated that home care provided for stroke patients and education of caregivers decreased the caregiver burden and increased their quality of life.
\end{abstract}

Key words: Caregivers; Education, nursing; Stroke; Quality of life; Home care services

\section{Introduction}

Stroke is an important and enormous public health problem in the world. Every year, nearly 15 million people experience a stroke attack throughout the world and 1.1 million people per year die due to stroke in Europe. Stroke is the third leading cause of death in the world. It is the second cause of death in Europe and the fourth cause of death in the USA and England $^{1,2}$. In Turkey, it is the second cause of death with $15 \%$ frequency $^{1}$. The mortality rate of stroke has been determined as 159 out of 100000 men and 181 out of

Correspondence to: Hacer Gok Ugur, PhD, Ordu University Faculty of Health Sciences, Department of Public Health Nursing, 52200, Ordu, Turkey

E-mail: hacer32@gmail.com

*This article has been produced from doctorate thesis.

Received November 2, 2015, accepted October 20, 2016
100000 women. Stroke mortality rate is higher in all age groups between 35 and 74, with some male predominance. On the other hand, compared to men, it is higher in women aged $\geq 75^{3}$. It has been reported that $21 \%-74 \%$ of post-stroke patients die in the acute phase of the disease, $15 \%-25 \%$ of patients die in the first year of the disease, and 5\%-14\% suffer new stroke episode in the same year ${ }^{4}$. Besides this, $40 \%$ of stroke patients are moderately disabled and 15\%-30\% are severely disabled when discharged from the hospital ${ }^{5}$. It is estimated that $25 \%-50 \%$ of post-stroke patients become partially or totally dependent on the others in daily activities $^{6,7}$. Furthermore, more than half of post-stroke patients are dependent on the others in their daily life activities ${ }^{8,9}$.

Caregivers of stroke patients have various problems such as depression, anxiety, exhaustion, hopelessness, fatigue, decreased physical health, social isolation, and 
economic problems ${ }^{10,11}$. Caregiving affects the caregiver quality of life because of its physiological, psychological, economic, and social dimensions ${ }^{7,12,13}$. The introduction of solutions by determining the caregiver burden increases the quality of life of both caregivers and their patients ${ }^{11,14,15}$. Regular support given to caregivers reduces the caregiver burden and increases their quality of life ${ }^{16,17}$. Public health nurses can educate and consult caregivers on how to overcome the problems, how to find sources of financial support, and how to stay healthy. Furthermore, caregivers can also be supported in terms of necessary controls of health organizations, psychological support, and their rights and responsibilities ${ }^{10,18}$.

Home nursing care given to stroke patients improves inabilities of patients in their daily activities ${ }^{19,20}$. The patient care reaches its goal when the nursing care is performed within a framework and the patient care is effective ${ }^{20,21}$. The model of daily living activities is one of the most appropriate models, which can be used in nursing care of stroke patients because it includes daily activities ${ }^{20}$.

The model of daily living activities identifies the person-centered care with a humanistic and holistic approach and it can be integrated into all service areas of the health care system ${ }^{22}$. This model has five components that were interrelated to each other and interacting with one another. These components are activities of daily living, life process, dependence/independence status, factors that affect life activities, and individuality in life ${ }^{20,23}$. In the model, the primary aim of nursing is to protect the person from problems and to teach how to live with the unsolvable problems ${ }^{20}$.

Public health nurses are significantly sufficient in home care of stroke patients, especially because of their caregiver roles in the treatment and rehabilitation $^{24}$. Home care provided for stroke patients by public health nurses using the model of daily living activities can be effective in reducing the caregiver burden and increasing their quality of life by improving the abilities of patients in their daily activities.

In this study, we aimed to determine the effect of home care of stroke patients and education of caregivers on their burden and quality of life.

\section{Study hypotheses}

Hypothesis 1: Home care provided for stroke patients by using the model of daily living activities burdens caregivers and impairs their quality of life.
Hypothesis 2: Training and consultancy reduce the burden of caregivers and improve their quality of life when providing health care for stroke patients.

\section{Subjects and Methods}

\section{Study design}

The study was conducted by using a true experimental method with pre-test and post-test control group.

\section{Setting and sample}

The study was conducted with stroke patients and their caregivers registered in the Ordu Provincial Directorate of Health between January 2012 and December 2013. Various health care services such as examination, investigation, analysis, treatment, medical care, rehabilitation, education, and consultation were provided by home care units.

In this study, a total of 104 patients diagnosed with hemorrhage or ischemia and registered in home care unit of the Ordu Provincial Directorate of Health were included. The patients and their caregivers were living in the city center. No sampling method was used in the study. Patients were given a random number from 1 to 104 . Accordingly, patients and their caregivers with odd numbers constituted control group and patients and their caregivers with even numbers constituted experimental group. Of the 52 patients in the experimental group, seven patients passed away and two patients moved out of the city. In the phase of data acquisition, of the 52 patients in the control group, eight patients passed away and one patient moved out of the city. For these reasons, the study was completed with 43 control and 43 experimental patients and caregivers.

The inclusion criterion for patients was as follows: patients should have previously had hemorrhagic or ischemic stroke. The inclusion criteria for caregivers were as follows: they should have been literate, should not have any vision or hearing loss or impairment, and should have been open to communication and cooperation.

\section{Ethical consideration}

Before starting the study, approval was obtained from the Atatürk University Graduate School of 
Health Sciences Ethics Committee and written permission was obtained from the Ordu Provincial Directorate of Health where the study was conducted. Before data collection, the purpose of the research was explained to participants and then they were asked to sign the informed consent form in accordance with the principle of self determination to protect their rights. During the study, no nursing interventions were made to the patients and caregivers in the control group. Nevertheless, the patients and caregivers used the services of home care unit when they needed. After applying the post-test, in accordance with the principle of equality, booklets such as Guidebook of Care of Stroke Patient and Education Booklet for Caregivers of Stroke Patients were also given to the control group. Besides, the control group patients were also looked after and their caregivers were educated and consulted after completion of the study.

\section{Measurements/instruments}

Patient and Caregiver Description Form, Patient Problem Identifying Form, Caregiving Burden Scale, and SF-36 Quality of Life Scale were used for data collection.

Patient and Caregiver Description Form: The form was prepared by researchers in accordance with the literature and it was used to determine the characteristics of patients and caregivers. This form consists of 12 questions related to age, sex, marital status, education, family type, social security, patient income, time of disease, stroke history, other diseases except for stroke, continuously used drugs or medications, and service type received from home care. The level of patient dependency was determined by Basic Activities of Daily Living (BADL) Scale ${ }^{25}$. Descriptive characteristics of the caregiver consists of 8 questions related to age, sex, education, work, existence of any chronic disease, relation to the patient, sufficiency in patient care by himself/herself, and receiving support in care.

Patient Problem Identifying Form: This form that contains 69 questions was prepared by the researcher in order to determine the problems of patients at home (providing and maintaining safe environment (5 questions), communication (20 questions), respiration (4 questions), nutrition (6 questions), excretion (7 questions), personal hygiene and clothing (12 questions), control of body heat ( 2 questions), movement ( 6 questions), working and entertainment (2 questions), sexu- ality (1 question), sleep (1 question) and death (3 questions) $)^{26-28}$.

Caregiving Burden Scale: The Caregiving Burden Scale (CBS) was developed by Zarit et al. in 1980 and it was adapted to Turkish by İnci and Erdem ${ }^{29,30}$. This scale, which is used to evaluate difficulties of caregivers, consists of 22 questions to determine the effect of the caregiver burden on someone's life. The scale has Likert type evaluation that varies between 0 and 4, indicating "never", "rarely", "sometimes", "very frequently" and "almost always". Minimum (0) and maximum (88) scores can be obtained from the scale. The higher score represents the higher difficulty in someone's life.

SF-36 Quality of Life Scale: The SF-36 Short Form was developed by Rand Corporation in order to evaluate the quality of life ${ }^{31}$. It was translated into Turkish and the validity and reliability studies were conducted by Koçyiğit et al. ${ }^{32}$. The SF-36 Quality of Life Scale consists of 36 questions. SF-36 has 8 sub-dimensions as follows: general sense of health, physical function, physical role, pain, vitality, social function, mental role and mental function, and 2 abstract fields of mental health and physical health. The abstract scores are expressed as a continuous variable, which varies between 0 and 100, where 0 indicates poor health and 100 indicates healthiness.

\section{Data collection/procedure}

Data were collected between September 2012 and May 2013. Data were primarily collected from the control group. The control group participants were asked to fill in the Patient and Caregiver Description Form, Caregiving Burden Scale and SF-36 Quality of Life Scale in the pre-test, and Caregiving Burden Scale and SF-36 Quality of Life Scale in the post-test. The pre-tests and post-tests were applied to control group participants by the researcher during home visits by using the face-to-face interview technique and within approximately 45-60 minutes. The experimental group filled in the Patient and Caregiver Description Form, Patient Problem Identifying Form, Caregiving Burden Scale and SF-36 Quality of Life Scale in the pre-test, and Caregiving Burden Scale and SF36 Quality of Life Scale in the post-test. The pre-tests and post-tests were applied by the researcher to the experimental group by home visits, with face-to-face technique and within 60-75 minutes on average. 


\section{Nursing interventions}

Nursing interventions were performed in experimental group patients and their caregivers 5 times fortnightly within the scope of the research ${ }^{32}$. The model of daily living activities was taken as a guide in nursing care of stroke patients. The appropriate nursing diagnosis that was approved by the North American Nursing Diagnosis Association (NANDA) (providing and maintaining safe environment 4 , communication 8 , respiration 2 , nutrition 3 , excretion 4 , personal hygiene and clothing 8 , control of body heat 2 , movement 2 , working and entertainment 1 , sexuality 1 , sleep 1 and death 1 nursing diagnosis) were used in the diagnosis. The nursing process that was prepared in line with the NANDA nursing diagnosis was used in nursing interventions $\mathrm{s}^{26-28}$. The education booklet was used as a guide in nursing care.

The Patient Problem Identifying Form was applied to patients in the experimental group in the first interview. Interventions were made according to the nursing process in the second, third, fourth, fifth and sixth home visits by using appropriate NANDA nursing diagnoses (the risk of injury, change in blood pressure, change in blood glucose level, failure to apply the treatment plan, anxiety, pain, impaired verbal communication, visual impairment, social isolation, change in the process of thought, impaired body image, adjustment disorder, ineffective airway patency, risk of aspiration, deglutition disorder, change of nutrition, lack of information, constipation, diarrhea, the risk of infection, infection, incapability of bath and hygienic care, failure in dressing and looking after oneself, the risk of losing the integrity of skin, losing the integrity of skin, change in the oral mucous membrane, change in body temperature, activity intolerance, lack of entertainment activities, change in sexual life, sleep disorder, death anxiety) in accordance with the problems identified according to this form.

Each patient in the experimental group was given home care 5 times (once in a fortnight) for about 40 minutes. No nursing interventions were made to $\mathrm{pa}^{-}$ tients in the control group.

Education and consultation services were given to the caregivers in the experimental group 5 times (once in a fortnight) for about 30 minutes during the home visits and with support of the booklet that was prepared considering the most common problems (protection and enhancement of health, dealing with nega- tive emotions, burnout, and social isolation) $)^{33-36}$. No education and consultation were given to caregivers in the control group throughout the study.

\section{Study variables}

Dependent variables: the burden of caregivers and their quality of life

Independent variables: training and consultancy provided to caregivers of stroke patients according to the model of daily living activities

Control variables: age of stroke patient, duration of the disease, level of dependency, age, gender, education status of the caregivers, status of caregivers concerning existence of a chronic disease, degree of proximity to the patient, and status of taking support maintenance

According to the results of the homogeneity test, there was no significant difference between experimental and control groups regarding control variables $(p>0.05)$. The nonsignificant difference between the experimental and control groups showed that both groups had similar features with respect to the specified variables.

\section{Data analysis}

Data evaluation was done by using the SPSS 15.0 (Statistical Package for Social Science) package program. Percentage distribution, independent sample ttest, signed t-test, Mann-Whitney U Test, and Wilcoxon signed-rank tests were used to evaluate data collected in the study.

\section{Results}

It was found that $48.8 \%$ of the experimental group patients were between 75 and 89 years old and $93 \%$ of them were dependent on others during their daily activities. On the other hand, $58 \%$ of the control group patients were aged between 75 and 89 , and $93 \%$ of them were dependent on others during their daily activities (Table 1).

In the experimental group, $44.3 \%$ of the caregivers were between 45 and 59 years old, $95.3 \%$ were female and $37.2 \%$ were patient's daughter-in-law. On the other hand, $58.3 \%$ of the caregivers in the control group were between the age of 45 and $59,88.4 \%$ were female and $32.6 \%$ were patient's daughter-in-law (Table 2). 
Table 1. Demographic characteristics of stroke patients

\begin{tabular}{|c|c|c|c|}
\hline \multicolumn{2}{|l|}{ Characteristic } & $\begin{array}{l}\text { Experimental group } \\
(\mathrm{N}=43)\end{array}$ & $\begin{array}{l}\text { Control group } \\
(\mathrm{N}=43)\end{array}$ \\
\hline \multirow[b]{2}{*}{ Age (years) } & & n (\%) & n (\%) \\
\hline & $\begin{array}{l}45-59 \\
60-74 \\
75-89 \\
\geq 90\end{array}$ & $\begin{array}{l}4(9.3) \\
15(34.9) \\
21(48.8) \\
3(7.0)\end{array}$ & $\begin{array}{l}2(4.7) \\
10(23.3) \\
25(58.0) \\
6(14.0)\end{array}$ \\
\hline Age (years) $($ mean $\pm \mathrm{SD})$ & & $74.74 \pm 11.84$ & $78.27 \pm 10.23$ \\
\hline Gender & $\begin{array}{l}\text { Female } \\
\text { Male }\end{array}$ & $\begin{array}{l}24(55.8) \\
19(44.2) \\
\end{array}$ & $\begin{array}{l}30(69.8) \\
13(30.2) \\
\end{array}$ \\
\hline Marital status & $\begin{array}{l}\text { Married } \\
\text { Bachelor }\end{array}$ & $\begin{array}{l}24(55.8) \\
19(44.2)\end{array}$ & $\begin{array}{l}19(44.2) \\
24(55.8)\end{array}$ \\
\hline Education & $\begin{array}{l}\text { Literate } \\
\text { Elementary school } \\
\text { Secondary school } \\
\text { High School }\end{array}$ & $\begin{array}{l}35(81.4) \\
4(9.2) \\
2(4.7) \\
2(4.7)\end{array}$ & $\begin{array}{l}35(81.4) \\
6(14.0) \\
1(2.3) \\
1(2.3)\end{array}$ \\
\hline Family type & $\begin{array}{l}\text { Nuclear family } \\
\text { Extended family }\end{array}$ & $\begin{array}{l}18(41.9) \\
25(58.1)\end{array}$ & $\begin{array}{l}19(44.2) \\
24(55.8)\end{array}$ \\
\hline Social security & $\begin{array}{l}\text { Yes } \\
\text { No }\end{array}$ & $\begin{array}{l}38(88.4) \\
5(11.6) \\
\end{array}$ & $\begin{array}{l}42(97.7) \\
1(2.3) \\
\end{array}$ \\
\hline Income status & $\begin{array}{l}\text { Income less than expense } \\
\text { Income equal to expense } \\
\text { Income more than expense }\end{array}$ & $\begin{array}{l}19(44.2) \\
24(55.8) \\
-\end{array}$ & $\begin{array}{l}13(30.2) \\
30(69.8) \\
-\end{array}$ \\
\hline \multicolumn{2}{|c|}{ Duration of disease (years) [mean(SD)] } & $6.04 \pm 5.78$ & $7.09 \pm 4.95$ \\
\hline BADL scale values & $\begin{array}{l}\text { Independent (0-6 points) } \\
\text { Semi independent ( } 7-12 \text { points) } \\
\text { Dependent (13-18 points) }\end{array}$ & $\begin{array}{l}- \\
3(7.0) \\
40(93.0)\end{array}$ & $\begin{array}{l}- \\
3(7.0) \\
40(93.0)\end{array}$ \\
\hline
\end{tabular}

$\mathrm{BADL}=$ Basic Activities of Daily Living scale

The difference in the mean CBS pre-test scores between the experimental and control group caregivers was not statistically significant $(p>0.05)$. However, there was a statistically significant difference between experimental and control groups according to the mean CBS post-test scores $(\mathrm{p}<0.001)$. While the mean post-test score of the experimental group was 37.05 12.30, the mean post-test score of the control group was $49.51 \pm 19.21$. The difference between the mean CBS pre-test and post-test scores of the experimental group caregivers was statistically significant $(\mathrm{p}<0.001)$. While the mean pre-test score of the experimental group caregivers was $48.28 \pm 14.06$, their mean posttest score decreased to $37.05 \pm 12.30$. Additionally, the difference between the mean CBS pre-test and posttest scores of the control group caregivers was statistically significant $(\mathrm{p}<0.01)$. While the mean pre-test score of the control group was $46.72 \pm 18.26$, their mean post-test score increased to $49.51 \pm 19.21$ (Table 3 ).

Differences in the mean pre-test scores for the quality of life scale general sense of health, physical function, physical role, mental role, social function, pain, vitality and mental function sub-dimensions, and mean scores for physical health and mental health between the experimental and control group caregivers were not statistically significant $(p>0.05)$. Differences in the mean post-test scores for the quality of life scale general sense of health, physical function, physical role, 
Table 2. Demographic characteristics of caregivers

\begin{tabular}{|l|l|l|l|}
\hline \multirow{2}{*}{ Characteristic } & $\begin{array}{l}\text { Experimental group } \\
(\mathrm{N}=43)\end{array}$ & $\begin{array}{l}\text { Control group } \\
(\mathrm{N}=43)\end{array}$ \\
\cline { 2 - 4 } & $\mathrm{n}(\%)$ & $\mathrm{n}(\%)$ \\
\hline Age (years) & $\leq 44$ & $12(27.9)$ & $7(16.2)$ \\
& $45-59$ & $19(44.3)$ & $25(58.3)$ \\
& $60-74$ & $9(20.9)$ & $7(16.2)$ \\
& $\geq 75$ & $3(6.9)$ & $4(9.3)$ \\
\hline Age (years) (mean $\pm \mathrm{SD})$ & & $51.20 \pm 13.45$ & $53.25 \pm 12.70$ \\
\hline Gender & Female & $41(95.3)$ & $38(88.4)$ \\
& Male & $2(4.7)$ & $5(11.6)$ \\
\hline Education & Literate & $12(27.9)$ & $9(20.9)$ \\
& Elementary school & $20(46.6)$ & $23(53.7)$ \\
& Secondary school & $2(4.6)$ & $3(6.9)$ \\
& High school & $8(18.6)$ & $6(13.9)$ \\
& University & $1(2.3)$ & $2(4.6)$ \\
\hline Work status & Working & $3(7.0)$ & $5(11.6)$ \\
& Not working & $40(93.0)$ & $38(88.4)$ \\
\hline Chronic disease & Yes & $26(60.5)$ & $27(62.8)$ \\
& No & $17(39.5)$ & $16(37.2)$ \\
\hline Chronic disease type & Herniated disc & $6(23.1)$ & $15(55.6)$ \\
& Hypertension & $10(38.5)$ & $6(22.2)$ \\
& Diabetes mellitus & $7(26.9)$ & $3(11.1)$ \\
& Goiter & $3(11.5)$ & $3(11.1)$ \\
\hline Relation to the patient & Spouse & $12(27.9)$ & $13(30.2)$ \\
& Daughter & $9(20.9)$ & $12(27.9)$ \\
& Son & $1(2.4)$ & $14(32.0)$ \\
& Daughter-in-law & $5(11.6)$ & $1(2.3)$ \\
\hline & Paid caregiver & & \\
\hline
\end{tabular}

social function, pain and mental function sub-dimensions, and mean scores for physical health and mental health did not reach statistical significance either (p>0.05) (Table 4).

The mean mental role post-test score of the experimental group caregivers and control group caregivers was $63.57 \pm 34.74$ and $47.29 \pm 20.87$, respectively. While the mean vitality post-test score of the experimental group caregivers was $41.86 \pm 17.22$, the respective value recorded in the control group caregivers was $32.56 \pm$ 24.89. There was a statistically significant difference between the experimental and control groups with respect to their mean mental role and vitality post-test scores $(\mathrm{p}<0.05)$ (Table 4$)$.
It was shown that the difference between the quality of life scale general sense of health, physical function, physical role, mental role, social function, pain, vitality, and mental function pre-test and post-test sub-dimension mean scores was statistically significant $(p<0.01)$. The quality of life scale general sense of health, physical function, physical role, mental role, social function, pain, vitality, and mental function subdimension post-test mean scores were higher than the pre-test mean scores. The difference between physical and mental health score pre-test and post-test mean scores of the experimental group caregivers was not statistically significant $(p>0.05)$. Furthermore, the difference between all sub-dimensions of the quality of 
Table 3. Comparison of the mean Caregiving Burden Scale scores between and within groups

\begin{tabular}{|l|l|l|l|}
\hline \multirow{2}{*}{ CBS } & $\begin{array}{l}\text { Experimental group } \\
(\mathrm{N}=43)\end{array}$ & $\begin{array}{l}\text { Control group } \\
(\mathrm{N}=43)\end{array}$ & \multirow{2}{*}{ Test and $\mathrm{p}$ values } \\
\cline { 2 - 3 } & $\chi \pm \mathrm{SD}$ & $\chi \pm \mathrm{SD}$ & \\
\hline Pre-test & $48.28 \pm 14.06$ & $46.72 \pm 18.26$ & ${ }^{1} \mathrm{t}=0.440, \mathrm{p}=0.660$ \\
Post-test & $37.05 \pm 12.30$ & $49.51 \pm 19.21$ & ${ }^{1} \mathrm{t}=-3.580, \mathrm{p}=0.000^{* *}$ \\
& ${ }^{2} \mathrm{t}=17.180, \mathrm{p}=0.000^{* *}$ & ${ }^{2} \mathrm{t}=-3.380, \mathrm{p}=0.002^{*}$ & \\
\hline
\end{tabular}

${ }^{*} \mathrm{p}<0.01 ;{ }^{*} \mathrm{p}<0.001 ;{ }^{1} \mathrm{t}=\mathrm{t}$-test for independent samples; ${ }^{2} \mathrm{t}=$ paired-t test CBS = Caregiving Burden Scale

Table 4. Comparison of the mean Quality of Life Scale scores between groups

\begin{tabular}{|c|c|c|c|c|c|}
\hline \multicolumn{2}{|c|}{ QLS sub-dimensions and scores } & \multirow{3}{*}{\begin{tabular}{|l|l}
$\begin{array}{l}\text { Experimental } \\
\text { group }(\mathrm{N}=43)\end{array}$ \\
$\chi \pm \mathrm{SD}$ \\
$44.07 \pm 31.16$ \\
$49.09 \pm 30.86$
\end{tabular}} & \multirow{3}{*}{\begin{tabular}{|l}
$\begin{array}{l}\text { Control group } \\
(\mathrm{N}=43)\end{array}$ \\
$\chi \pm \mathrm{SD}$ \\
$44.93 \pm 31.49$ \\
$43.72 \pm 31.28$ \\
\end{tabular}} & \multicolumn{2}{|c|}{ Test and $p$ values } \\
\hline \multirow{2}{*}{$\begin{array}{l}\text { General sense of } \\
\text { health }\end{array}$} & Pre-test & & & $\mathrm{U}=900.50$ & 0.835 \\
\hline & Post-test & & & $\mathrm{U}=835.00$ & 0.439 \\
\hline \multirow{2}{*}{ Physical function } & Pre-test & $57.79 \pm 31.70$ & $57.56 \pm 32.79$ & $U=919.00$ & 0.962 \\
\hline & Post-test & $68.60 \pm 26.73$ & $57.56 \pm 31.31$ & $\mathrm{U}=728.50$ & 0.090 \\
\hline \multirow{2}{*}{ Physical role } & Pre-test & $53.49 \pm 43.84$ & $49.42 \pm 49.25$ & $U=895.00$ & 0.783 \\
\hline & Post-test & $63.95 \pm 35.06$ & $46.51 \pm 47.43$ & $\mathrm{U}=722.00$ & 0.065 \\
\hline \multirow{2}{*}{ Mental role } & Pre-test & $51.94 \pm 27.51$ & $48.84 \pm 26.58$ & $\mathrm{U}=902.50$ & 0.836 \\
\hline & Post-test & $63.57 \pm 34.74$ & $47.29 \pm 20.87$ & $\mathrm{U}=638.00$ & $0.009^{* *}$ \\
\hline \multirow{2}{*}{ Social function } & Pre-test & $54.94 \pm 28.76$ & $56.40 \pm 36.74$ & $\mathrm{U}=875.00$ & 0.666 \\
\hline & Post-test & $69.48 \pm 23.83$ & $55.23 \pm 34.96$ & $\mathrm{U}=726.00$ & 0.083 \\
\hline \multirow{2}{*}{ Pain } & Pre-test & $22.88 \pm 16.87$ & $24.37 \pm 17.01$ & $\mathrm{U}=880.00$ & 0.690 \\
\hline & Post-test & $29.21 \pm 13.67$ & $25.70 \pm 16.32$ & $\mathrm{U}=825.00$ & 0.361 \\
\hline \multirow{2}{*}{ Vitality } & Pre-test & $30.47 \pm 19.45$ & $33.49 \pm 23.54$ & $\mathrm{U}=873.00$ & 0.655 \\
\hline & Post-test & $41.86 \pm 17.22$ & $32.56 \pm 24.89$ & $\mathrm{U}=678.00$ & $0.033^{*}$ \\
\hline \multirow{2}{*}{ Mental function } & Pre-test & $54.94 \pm 28.76$ & $44.28 \pm 24.77$ & $\mathrm{U}=896.50$ & 0.809 \\
\hline & Post-test & $69.48 \pm 23.83$ & $45.21 \pm 24.51$ & $\mathrm{U}=830.00$ & 0.413 \\
\hline \multirow{2}{*}{ Physical health score } & Pre-test & $40.12 \pm 6.98$ & $40.21 \pm 6.11$ & $\mathrm{U}=899.00$ & 0.826 \\
\hline & Post-test & $40.02 \pm 6.35$ & $40.33 \pm 6.66$ & $\mathrm{U}=888.00$ & 0.753 \\
\hline \multirow{2}{*}{ Mental health score } & Pre-test & $39.38 \pm 6.25$ & $38.52 \pm 4.62$ & $\mathrm{U}=818.00$ & 0.358 \\
\hline & Post-test & $40.51 \pm 6.34$ & $38.33 \pm 4.87$ & $\mathrm{U}=715.00$ & 0.070 \\
\hline
\end{tabular}

QLS = Quality of Life Scale; ${ }^{*} \mathrm{p}<0.05 ;{ }^{*} \mathrm{p}<0.01$; conformity of variables with normal distribution was measured with Kolmogorov-Smirnov test, and therefore Mann-Whitney U tests were used

life scale and physical and mental health pre-test and post-test mean scores of the control group caregivers was not statistically significant $(\mathrm{p}>0.05)$ (Table 5).

\section{Discussion}

Stroke is one of the important health issues in the world, as well as in Turkey, associated with high mortal- ity rates ${ }^{1,2,37}$. Caregivers of stroke patients have various physical, psychological, social and economic problems because of the health care process ${ }^{12,13}$. The aim of this study was to determine the effect of home care of stroke patients and education of caregivers on their burden and quality of life. Study findings are discussed below.

Even though no statistically significant difference was found in CBS pre-test mean scores between the 
Table 5. Comparison of the mean Quality of Life Scale pre-test and post-test scores within groups

\begin{tabular}{|c|c|c|c|c|c|c|c|}
\hline \multirow{2}{*}{\multicolumn{2}{|c|}{ QLS sub-dimensions }} & \multicolumn{3}{|c|}{ Experimental group $(\mathrm{N}=43)$} & \multicolumn{3}{|c|}{ Control group $(\mathrm{N}=43)$} \\
\hline & & Median & $\chi \pm \mathrm{SD}$ & Test and $\mathrm{p}$ values & Median & $\chi \pm \mathrm{SD}$ & Test and $\mathrm{p}$ values \\
\hline \multirow{2}{*}{$\begin{array}{l}\text { General sense } \\
\text { of health }\end{array}$} & Pre-test & 50.00 & $44.07 \pm 31.16$ & \multirow{2}{*}{$\mathrm{Z}=4.22, \mathrm{p}=0.000^{* *}$} & 45.00 & $44.93 \pm 31.49$ & \multirow{2}{*}{$\mathrm{Z}=1.23, \mathrm{p}=0.220$} \\
\hline & Post-test & 52.00 & $49.09 \pm 30.86$ & & 42.00 & $43.72 \pm 31.28$ & \\
\hline \multirow{2}{*}{$\begin{array}{l}\text { Physical } \\
\text { function }\end{array}$} & Pre-test & 55.00 & $57.79 \pm 31.70$ & \multirow{2}{*}{$\mathrm{Z}=4.84, \mathrm{p}=0.000^{* *}$} & 60.00 & $57.56 \pm 32.79$ & \multirow{2}{*}{$Z=0.35, p=0.972$} \\
\hline & Post-test & 75.00 & $68.60 \pm 26.73$ & & 55.00 & $57.56 \pm 31.31$ & \\
\hline \multirow{2}{*}{ Physical role } & Pre-test & 50.00 & $53.49 \pm 43.84$ & \multirow{2}{*}{$\mathrm{Z}=3.02, \mathrm{p}=0.003^{*}$} & 25.00 & $49.42 \pm 49.25$ & \multirow{2}{*}{$Z=0.62, p=0.538$} \\
\hline & Post-test & 50.00 & $63.95 \pm 35.06$ & & 25.00 & $46.51 \pm 47.43$ & \\
\hline \multirow{2}{*}{ Mental role } & Pre-test & 33.33 & $51.94 \pm 27.51$ & \multirow{2}{*}{$Z=2.80, p=0.005^{*}$} & 33.33 & $48.84 \pm 26.58$ & \multirow{2}{*}{$Z=0.29, p=0.772$} \\
\hline & Post-test & 66.67 & $63.57 \pm 34.74$ & & 33.33 & $47.29 \pm 20.87$ & \\
\hline \multirow{2}{*}{$\begin{array}{l}\text { Social } \\
\text { function }\end{array}$} & Pre-test & 50.00 & $54.94 \pm 28.76$ & \multirow{2}{*}{$\mathrm{Z}=5.14, \mathrm{p}=0.000^{* *}$} & 62.50 & $56.40 \pm 36.74$ & \multirow{2}{*}{$Z=0.70, p=0.486$} \\
\hline & Post-test & 75.00 & $69.48 \pm 23.83$ & & 62.50 & $55.23 \pm 34.96$ & \\
\hline \multirow{2}{*}{ Pain } & Pre-test & 22.00 & $22.88 \pm 16.87$ & \multirow{2}{*}{$\mathrm{Z}=3.24, \mathrm{p}=0.001^{*}$} & 31.00 & $24.37 \pm 17.01$ & \multirow{2}{*}{$Z=1.31, p=0.190$} \\
\hline & Post-test & 41.00 & $29.21 \pm 13.67$ & & 31.00 & $25.70 \pm 16.32$ & \\
\hline \multirow{2}{*}{ Vitality } & Pre-test & 30.00 & $30.47 \pm 19.45$ & \multirow{2}{*}{$\mathrm{Z}=5.49, \mathrm{p}=0.000^{* * *}$} & 35.00 & $33.49 \pm 23.54$ & \multirow{2}{*}{$Z=0.69, p=0.490$} \\
\hline & Post-test & 45.00 & $41.86 \pm 17.22$ & & 30.00 & $32.56 \pm 24.89$ & \\
\hline \multirow{2}{*}{$\begin{array}{l}\text { Mental } \\
\text { function }\end{array}$} & Pre-test & 50.00 & $54.94 \pm 28.76$ & \multirow{2}{*}{$\mathrm{Z}=4.90, \mathrm{p}=0.000^{* *}$} & 48.00 & $44.28 \pm 24.77$ & \multirow{2}{*}{$Z=0.72, p=0.474$} \\
\hline & Post-test & 75.00 & $69.48 \pm 23.83$ & & 48.00 & $45.21 \pm 24.51$ & \\
\hline \multirow{2}{*}{$\begin{array}{l}\text { Physical } \\
\text { health score }\end{array}$} & Pre-test & 39.55 & $40.12 \pm 6.98$ & \multirow{2}{*}{$Z=0.25, p=0.804$} & 41.86 & $40.21 \pm 6.11$ & \multirow{2}{*}{$Z=0.40, p=0.690$} \\
\hline & Post-test & 39.92 & $40.02 \pm 6.35$ & & 40.31 & $40.33 \pm 6.66$ & \\
\hline \multirow{2}{*}{$\begin{array}{l}\text { Mental } \\
\text { health score }\end{array}$} & Pre-test & 39.70 & $39.38 \pm 6.25$ & \multirow{2}{*}{$Z=1.02, p=0.308$} & 38.16 & $38.52 \pm 4.62$ & \multirow{2}{*}{$Z=0.70, p=0.482$} \\
\hline & Post-test & 41.04 & $40.51 \pm 6.34$ & & 37.73 & $38.33 \pm 4.87$ & \\
\hline
\end{tabular}

QLS = Quality of Life Scale; ${ }^{*}<<0.01 ;{ }^{* *} \mathrm{p}<0.001$; conformity of the variables with normal distribution was measured with Kolmogorov-Smirnov test and therefore Mann-Whitney U tests were used

experimental and control group caregivers, there was a statistically significant difference between their posttest mean scores $(\mathrm{p}<0.001)$ (Table 3$)$. This finding was similar to the results of Kalra et al..$^{38}$, who report a statistically significant difference in post-test CBS mean scores between the experimental and control group caregivers. According to these findings, the burden of caregivers of stroke patients can be mitigated by training and consultancy services offered to caregivers.

A statistically significant difference was found between the CBS pre-test and post-test mean scores in the experimental group caregivers $(p<0.001)$ (Table 3$)$. The findings of this study were similar to those reported from the studies conducted by Teng et al., Kalra et al., Björkdahl et al. and Bhattacharjee et al., in which significant changes were observed and nursing care of stroke patients and education of caregivers was demonstrated to decrease the burden of caregivers ${ }^{38-41}$. Similarly, other studies conducted by McCullagh et al. and Temizer and Gözüm showed that education and consultation offered to caregivers reduced their bur$\operatorname{den}^{14,42}$. In the studies conducted by Louie et al. carried out for 1 month, Van den Heuvel et al. for 2 months and Grant et al. for 3 months, the researchers report that education given to caregivers increased their knowledge level, but did not affect their burden ${ }^{43-45}$. In these studies, it was possible that short home visits and face-to-face education might not have changed the caregiver burden. Studenski et al. and Van Heugten et al. indicated that periodical interventions on stroke patients and caregivers for at least 3 months were effective ${ }^{46,47}$. The present study was performed for 3 months by both providing home care to patients according to the model of daily living activities, and education and consultation to the caregivers once in a fortnight. According to the findings, these interventions and applications could reduce the caregiver burden. 
A statistically significant difference was found between the CBS pre-test and post-test mean scores in the control group caregivers $(\mathrm{p}<0.01)$ (Table 3$)$. The CBS post-test mean scores of the control group caregivers increased compared to their pre-test scores, and this might be because of the increased caregiver burden in time. On the other hand, Temizer and Gözüm conducted a study on caregivers of stroke patients and found that the burden of caregivers increased in time in the control group, and this finding supports our results ${ }^{42}$.

No statistically significant difference was found in the quality of life scale general sense of health, physical function, physical role, mental role, social function, pain, vitality, and mental function sub-dimensions and physical health and mental health pre-test mean scores between the experimental and control group caregivers $(p>0.05)$. There was a significant difference in the mental role and vitality sub-dimensions of the quality of life scale post-test mean scores between the experimental and control group caregivers $(\mathrm{p}<0.05)$ (Table 4). Similar to the study conducted by Grant et al., the sub-dimensions (vitality, mental role, and mental function) of the life quality scale mean scores increased ${ }^{45}$. Mant et al. report that vitality and mental function mean scores of the caregivers after education were higher than the scores of the control group ${ }^{48}$. Although there was no statistically significant difference in the mental function post-test mean scores between the experimental and control group caregivers, the mental function post-test mean score of the experimental group caregivers was higher than the scores of the control group. Mental role represents the effects of emotional problems such as depression or anxiety on daily activities of an individual. Mental function represents general mental health in terms of psychological distress and well-being. On the other hand, vitality represents objective evaluation of the fatigue level. In this study, we observed recovery in the general psychological status of caregivers and the levels of caregiver fatigue were decreased due to the effect of home care of stroke patients, as well as education and consultation provided to caregivers. This finding is consistent with the literature ${ }^{45,48}$.

There was a statistically significant difference between all sub-dimensions of quality of life scale pretest and post-test mean scores of the experimental group caregivers $(\mathrm{p}<0.01)$ (Table 5). Some researchers report that the quality of life of experimental caregiv- ers was higher compared to the control group ${ }^{14,35,38,48,49}$. Mant et al. found that education and consultation given to the caregivers once in hospital and 3 times at home by phone increased their vitality, physical function, pain, general sense of health and mental function sub-dimension mean scores ${ }^{48}$. However, Anderson et $a l$. and Louie et al. report that 1-month education and consultation did not affect the quality of life scale mean scores of caregivers ${ }^{43,50}$. Similarly, Van den Heuvel et al. indicated that the quality of life scale mean scores of caregivers were not affected by 2 -month education and consultation ${ }^{47}$. Furthermore, it was shown by Hackett et al. that education given once before hospital discharge did not affect caregiver quality of life mean scores ${ }^{51}$. These differences might be due to the short duration of studies. Van Heugten et al. found periodical interventions for at least 3 months to be necessary for change in the quality of life ${ }^{34}$. In the present study, regular home care of stroke patients, as well as periodical education and consultation of caregivers took 3 months and these interventions led to an increase in their quality of life.

There was no statistically significant difference between the quality of life scale, physical and mental health scores, pre-test and post-test mean scores of the experimental group caregivers ( $p>0.05)$ (Table 5). In this case, a larger sample size is needed to be able to observe the change in these scores.

\section{Study limitations}

This study had several limitations. The study was conducted with patients and their caregivers registered in a home care unit in only one province of Turkey. Therefore, findings of this study cannot be generalized to all stroke patients and their caregivers registered to home care units throughout Turkey. Furthermore, in this study, home care was provided to stroke patients, with education and consultancy services provided for their caregivers. The overall effects of these interventions on caregiver burden and quality of life were examined. However, it can also be useful to examine separate effects of these interventions on caregiver burden and quality of life in further studies.

\section{Conclusion}

This study revealed that home care for stroke patients coupled with education of caregivers decreased 
the caregiver burden and increased their quality of life. The findings of this study are very important for public health nurses who are working with stroke patients and their caregivers. In line with these results, the model of daily living activities can be effectively used by public health nurses, and education and consultancy services related to home care can be effectively offered to caregivers of stroke patients, stroke patients and their caregivers can be evaluated together, and caregivers can be informed about their own health status by receiving consultancies. Furthermore, it is recommended to conduct long-term studies with large sample groups.

\section{References}

1. Yardım N, Bora B, Mollahaliloğlu S. Türkiye ulusal hastalık yükü ve maliyet etkililik çalışması: hastalık yükü hesaplamaları. Türkiye'de Sık Karşılaşılan Hastalıklar I. Sempozyum Dizisi. 2007:9-24. (in Turkish).

2. Stroke Association. Stroke statistics. 2013-[cited 2013 Sep 10]. Available from: http://www.stroke.org.uk/sites/default/files/ stroke\%20statistics.pdf

3. Dinç G, Sözmen K, Gerçeklioğlu G, Arık H, Critchley J, Ünal B. Decreasing trends in cardiovascular mortality in Turkey between 1988 and 2008. BMC Public Health. 2013 Sep 30;13:896, PubMed PMID: 24079269, https://doi.org/10.1186/1471-2458-13-896

4. Stineman MG, Ross RN, Hamilton BB, Maislin G, Bates B, Granger CV.Inpatient rehabilitation after stroke: a comparison of lengths of stay and outcomes in the Veterans Affairs and non-veterans affairs health care system. Med Care. 2001; 39(2):123-37, PubMed PMID: 11176550, https://doi.org/ 10.1097/00005650-200102000-00003

5. Eyigör S. General rehabilitation principles, quality of life and outcome assessment in patients with stroke. Turk J Phys Med Rehabil. 2007;53(Suppl 1):19-25. (in Turkish).

6. Fadıloğlu Ç. Rehabilitation of stroke. III. Aegean Internal Medicine Days. Internal Diseases Nursing Congress Book. Meta edition and printing services, İzmir, 2004. p. 249-81. (in Turkish).

7. White CL, Lauzon S, Yaffe MJ, Wood-Dauphine S. Toward a model of quality of life for family caregivers of stroke survivors. Qual Life Res. 2004 Apr;13(3):625-38, PubMed PMID: 15130026, https://doi.org/10.1023/B:QURE.00000 21312.37592.4f

8. Aşiret GD, Kapucu S. Burden of caregivers of stroke patients. Turk J Neurol. 2013;19(1):5-10, https://doi.org/10.4274/ Tnd.60234 (in Turkish).

9. Çoban O. Definitions, classification, epidemiology and risk factors in cerebrovascular diseases. 2013-[cited 2013 July 22].
Available from: http://www.itfnoroloji.org/svh/bdhtanimlar. htm. (in Turkish).

10. Karadakovan A. Care of internal and surgical diseases. In: Karadakovan A, Aslan FE, editors. Identifying Methods of Nervous System. Adana: Nobel Bookstore; 2010. p. 1189-99. (in Turkish).

11. Atagün Mİ, Balaban ÖD, Atagün Z, Elagöz M, Yılmaz Özpolat A. Kronik hastalıklarda bakım veren yükü. Psikiyatride GüncelYaklaşımlar. 2011;3:513-52,http://dx.doi.org/10.5455/ cap.20110323 (in Turkish)

12. Adams C. Quality of life for caregivers and stroke survivors in the immediate discharge period. Appl Nurs Res. 2003 May;16(2):126-30, PubMed PMID: 12764724, https://doi. org/10.1016/S0897-1897(03)00005-3

13. Walling $\mathrm{AD}$. Caregiver training and outcomes in stroke patients. Am Fam Physician. 2005 Mar 1;71(5):990-2.

14. McCullagh E, Brigstocke G, Donaldson N, Kalra L. Determinants of caregiving burden and quality of life in caregivers of stroke patients. Stroke. 2005 Oct;36(10):2181-6, PubMed PMID: 16151029, https://doi.org/10.1161/01.STR.0000181 755.23914 .53

15. Yıldırım S, Engin E, Başkaya VA. The burden of caregivers of stroke patients and the factors affecting the burden. Arch Neuropsychiatry. 2013;50:169-74, https://doi.org/10.4274/npa. y6505 (in Turkish).

16. Jullamate P, de Azeredo Z, Pául C, Subgranon R. The stroke patient caregivers: who they are and what they need. Cerebrovasc Dis. 2006;21(1-2):128-33, PubMed PMID: 16340188, https://doi.org/10.1159/000090211

17. Gündüz B, Erhan B. Quality of life of stroke patients' spouses living in the community in Turkey: controlled study with short form-36 questionnaire. J Neurol Sci Turk. 2008;25(4):226-34. (in Turkish).

18. Cecil R, Thompson K, Parahoo K, McCaughan E. Towards an understanding of the lives of families affected by stroke: a qualitative study of home carers. J Adv Nurs. 2013 Aug;69(8): 1761-70, PubMed PMID: 23215761, https://doi.org/10.1111/ jan. 12037

19. Burton CR. Re-thinking stroke rehabilitation: the Corbin and Strauss chronic illness trajectory framework. J Adv Nurs. 2000 Sep;32(3):595-602, PubMed PMID: 11012801, https://doi. org/10.1046/j.1365-2648.2000.01517.x

20. Akça Ay F. What is theory? Occupational theories and theorists. In: Akça Ay F, editor. Basic Concepts and Skills in Health Practises. İstanbul: Nobel Medicine Bookstores; 2012. p.30-58. (in Turkish).

21. Alligood MR. Philosophies, models and theories: critical thinking structures. In: Alligood MR, Tomey AM, editors. Nursing Theory: Uutilization and Aapplication. St. Louis: Mosby/Elsevier; 2006. p. 43-65.

22. Kaya N. Life model. In: Babadağ K, Aştı TA, editors. Fundamentals of Nursing Practice Guide. İstanbul: Istanbul Medical Publishing House; 2008. p. 1-7. (in Turkish). 
23. Sabuncu N, Erkal İlhan S. Basic concepts in nursing. In: Sabuncu N, editor. Principles and Practices in Nursing Care. Ankara: Alter Publishing; 2011. p. 9-43. (in Turkish).

24. Sayan A. Home care in today. J Atatürk Univ Nurs School. 2004;7(3):91-6. (in Turkish).

25. Feinberg TE, Farah MJ. Katz index of activities of daily living. Behavioral Neurology and Neuuropsychology. USA; 1997. p. 633.

26. Birol L. Nursing process. Izmir: Etki Publications; 2009. (in Turkish).

27. Carpenito-Moyet LJ. Handbook of nursing diagnosis. Translation: Erdemir F. Handbook of Nursing Diagnosis. Istanbul: Nobel Bookstores; 2005. (in Turkish).

28. Durna Z, Akın S, Özdilli K. Nursing care plan for stroke patient. In: Durna Z, editor. Internal Diseases Nursing Practise Gguidebook. Istanbul: Cinius Publications; 2009. p. 200-22. (in Turkish).

29. Zarit SH, Reever KE, Back-Peterson J. Relatives of the impaired elderly: correlates of feelings of burden. Gerontologist. 1980;20(6):649-55, https://doi.org/10.1093/geront/20.6.649.

30. Inci FH, Erdem M. Validity and reliability of the Turkish version of the burden interview. J Atatürk Univ Nurs School. 2008;11:85-95. (in Turkish).

31. Ware JE, Sherbourne CD. The MOS 36-item short-form health survey (SF-36) 1: conceptual framework and item selection. Med Care. 1992 Jun;30(6):473-83, PubMed PMID: 1593914, http:// dx.doi.org/10.1097/00005650-199206000-00002.

32. Koçyiğit H, Aydemir O, Fisek G, Olmez N, Memiş A. Validity and reliability of Turkish version of Short Form 36: a study of patients with rheumatoid disorder. Turk J Drug Ther. 1999; 12(1):102-6. (in Turkish).

33. Visser-Meily A, Van Heugten C, Post M, Schepers V, Lindeman E. Intervention studies for caregivers of stroke survivors: a critical review. Patient Educ Couns. 2005 Mar;56(3):257-67, PubMed PMID: 15721967, https://doi.org/10.1016/j.pec.2004.02.013.

34. Van Heugten C, Visser-Meily A, Post M, Lindeman E. Care for carers of stroke patients: evidence-based clinical practice guidelines. J Rehabil Med. 2006 May;38(3):153-8, PubMed PMID: 16702081, https://doi.org/10.1080/16501970500441898.

35. Wilz G, Barskova T. Evaluation of a cognitive behavioral group intervention program for spouses of stroke patients. Behav Res Ther. 2007 Oct;45(10):2508-17, PubMed PMID: 17555707, https://doi.org/10.1016/j.brat.2007.04.010.

36. Selçuk B, Bektaşoğlu S. Stroke and family. In: Arasıl T, Öztürk EA, editors. Stroke Recovery and Rehabilitation. Ankara: Pelikan Bookstore; 2012. p. 683-95. (in Turkish).

37. Kes VB, Jurašić MJ, Zavoreo I, Lisak M, Jeleč V, Matovina LZ. Age and gender differences in acute stroke hospital patients. Acta Clin Croat. 2016;55:69-78, PubMed PMID: 27333721, https://doi.org/10.20471/acc.2016.55.01.11.
38. Kalra L, Evans A, Perez I, Melbourn A, Patel A, Knapp M, et al. Training carers of stroke patients: randomised controlled trial. BMJ. 2004;328(7448):1099-104, PubMed PMID: 1513 0977, https://doi.org/10.1136/bmj.328.7448.1099

39. Teng J, Mayo NE, Latimer E, Hanley J, Wood-Dauphinee S, Cote, $\mathrm{R}$, et al. Costs and caregiver consequences of early supported discharge for stroke patients. Stroke. 2003;34(2): 528-36, PubMed PMID: 12574571, https://doi.org/10.1161 /01.STR.0000049767.14156.2C

40. Björkdahl A, Nilsson AL, Sunnerhagen KS. Can rehabilitation in the home setting reduce the burden of care for the next-ofkin of stroke victims? J Rehabil Med. 2007;39(1):27-32, PubMed PMID: 17225034, https://doi.org/10.2340/16501977-0001

41. Bhattacharjee M, Vairale J, Gawali K, Praful M. Factors affecting burden on caregivers of stroke survivors: population-based study in Mumbai (India). Ann Indian Acad Neurol. 2012; 15(2):113-9, PubMed PMID: 22566724, https://doi.org/ 10.4103/0972-2327.94994

42. Temizer H, Gözüm S. Impact of nursing care initiatives on the knowledge level and perception of caregiving difficulties of family members providing home care to stroke patients. HealthMED. 2012;6(8):2681-8.

43. Louie SW, Liu PK, Man DW. The effectiveness of a stroke education group on persons with stroke and their caregivers. Int J Rehabil Res. 2006;29(2):123-9, PubMed PMID: 1660 9323, https://doi.org/10.1097/01.mrr.0000191851.03317.f0

44. Van den Heuvel ETP, de Witte LP, Nooyen IH, Sanderman R, Jong BM. Short-term effects of a group support program and an individual support program for caregivers of stroke patients. Patient Educ Couns. 2000;40(2):109-20, PubMed PMID: 10771365, https://doi.org/10.1016/S0738-3991(99)00066-X

45. Grant JS, Elliott TR, Weaver M, Bartolucci AA, Giger JN. Telephone intervention with family caregivers of stroke survivors after rehabilitation. Stroke. 2002;33(8):2060-5, PubMed PMID: 12154263 , https://doi.org/10.1161/01.STR.0000020711.38824.E3

46. Studenski S, Duncan PW, Perera S, Reker D, Lai SM, Richards L. Daily functioning and quality of life in a randomized controlled trial of therapeutic exercise for subacute stroke survivors. Stroke. 2005;36(8):1764-70, PubMed PMID: 16040590, https://doi.org/10.1161/01.STR.0000174192.87887.70

47. Van den Heuvel ETP, Witte LP, Stewart RE, Schure LM, Sanderman R, Meyboom-de Jong B. Long-term effects of a group support program and an individual support program for informal caregivers of stroke patients: which caregivers benefit the most? Patient Educ Couns. 2002 Aug;47(4):291-9, PubMed PMID: 12135820, https://doi.org/10.1016/S0738-3991(01) 00230-0

48. Mant J, Carter J, Wade DT, Winner S. Family support for stroke: a randomized controlled trial. Lancet. 2000;356(9232): 808-13, PubMed PMID: 11022928, https://doi.org/10.1016/ S0140-6736(00)02655-6 
49. Aktaş A. The effect of the education given to the relations of patients on the relation's quality of life and anxiety and depressive symptom level [dissertation]. Graduate School of Health Sciences Department of Fundamentals of Nursing: İstanbul University; 2010. (in Turkish).

50. Anderson C, Rubenach S, Mhurchu CN, Clark MS, Spencer $\mathrm{C}$, Winsor A. Home or hospital for stroke rehabilitation? Results of a randomized controlled trial 1: Health outcomes at 6 months. Stroke. 2000;31(5):1024-31, PubMed PMID: 10797161, https://doi.org/10.1161/01.STR.31.5.1024

51. Hackett ML, Vandal AC, Anderson CS, Rubenach SE. Longterm outcome in stroke patients and caregivers following accelerated hospital discharge and home-based rehabilitation. Stroke. 2002;33(2):643-5, PubMed PMID: 11823686, https:// doi.org/10.1161/str.33.2.643

Sažetak

\title{
UČINAK KUĆNE NJEGE BOLESNIKA S MOŽDANIM UDAROM I IZOBRAZBE NJEGOVATELJA NA OPTEREĆENJE I KVALITETU ŽIVOTA NJEGOVATELJA
}

\author{
H. Gok Ugur i B. Erci
}

Cilj ovoga istraživanja bio je utvrditi učinak kućne njege bolesnika s moždanim udarom i izobrazbe njegovatelja na opterećenje i kvalitetu života njegovatelja. Istraživanje je provedeno primjenom prave eksperimentalne metode s kontrolnom skupinom prije i poslije testiranja. U istraživanje je bilo uključeno 43 eksperimentalna i 43 kontrolna bolesnika i njegovatelja. Podaci su se prikupljali pomoću sljedećih upitnika: Patient and Caregiver Description Form, Patient Problem Identifying Form, Caregiving Burden Scale i SF-36 Quality of Life Scale. Sestrinska njega se bolesnicima eksperimentalne skupine pružala prema modelu svakodnevnih aktivnosti, dok u kontrolnoj skupini nije bilo nikakve intervencije. U statističkoj analizi primijenjena je distribucija postotka, $\chi^{2}$, t-test za neovisne uzorke, parni t-test, Mann-Whitney U test i Wilcoxon signed-rank test. Nije bilo statistički značajne razlike srednjih vrijednosti prije i poslije testiranja između njegovatelja eksperimentalne i kontrolne skupine. Statistički značajna razlika utvrđena je između srednjih vrijednosti svih pod-dimenzija ljestvice kvalitete života prije i poslije testiranja u njegovatelja eksperimentalne skupine. Ovo istraživanje je pokazalo da kućna njega bolesnika s moždanim udarom uz izobrazbu njegovatelja smanjuje opterećenje i poboljšava kvalitetu života njegovatelja.

Ključne riječi: Njegovatelji; Sestrinska izobrazba; Moždani udar; Kvaliteta života; Kućna njega 